\title{
Tree species preference and land rehabilitation perspective by local community: Case study in Bondowoso, East Java, Indonesia
}

\author{
SETYAWAN AGUNG DANARTO^, SUGENG BUDIHARTA, FAUZIAH \\ Purwodadi Botanic Gardens, Research Center for Plant Conservation and Botanic Gardens, Indonesian Institute of Sciences. J1. Raya Surabaya-Malang \\ Km. 65, Purwodadi, Pasuruan 67163, East Java, Indonesia. Tel.: +62-343-615033, `email: setyawan.10535@gmail.com
}

Manuscript received: 17 July 2019. Revision accepted: 30 August 2019.

\begin{abstract}
Danarto SA, Budiharta S, Fauziah. 2019. Tree species preference and land rehabilitation perspective by local community: Case study in Bondowoso, East Java, Indonesia. Asian J For 3: 54-63. Forest and land rehabilitation efforts require socio-economic assessment to enhance the likelihood of success when such efforts are implemented on the ground. This study aimed to find out local community's preference on tree species used for rehabilitation programs and their perspective that influence such selections in regard to social, economic and ecological objectives of land management. The study was conducted Gubrih sub-watershed, Sampean watershed in Bondowoso District, East Java, Indonesia which provided an ideal case study of land rehabilitation. Questionnaires were distributed to respondents chosen randomly to select tree species that have ecological and/or economic values. Result of the study showed that among 62 species of trees listed in the questionnaire, there were 45 species chosen by the respondents. There were 13 species of trees selected by more than $20 \%$ of total respondents (high preferred), suggesting the potential list of species for rehabilitation programs in the region. Local community in Gubrih Sub-watershed had understood the importance of trees as a source of income as well as a measure to conserve environmental functions. This was strengthened with land-use systems they selected which preferred tree-based land-use systems, such as in the form of plantation of timber species and agroforestry over dry land agriculture. The findings of this study suggested that there is opportunity in rehabilitating degraded lands in Sampean watershed using tree species preferred by local communities under the land use system of timber plantation or agroforestry. Our study demonstrates that similar strategy of incorporating ecological and socio-economic perspectives could be applied to another regional context to enhance the chance of success of rehabilitation programs.
\end{abstract}

Keywords: Land degradation, land rehabilitation, trees preferences, social-ecological systems, watershed

\section{INTRODUCTION}

Deforestation and land degradation in Indonesia, especially in Java, have been occurring since long time ago which is caused by forest clearing for agricultural activities to feed the expanding population and for developing settlements, resulting in the decreasing extent of forested areas (Nawir et al. 2007). Land conversion and exploitation from forested or tree-based vegetation into different land uses (such as agriculture, urban settlement, and industries) sometimes lack to consider soil conservation practices, causing soil degradation (Faisol and Indarto 2010). Soil degradation in the form of erosion can lead to further environmental deterioration through sedimentation, pollution and increased flooding (Morgan 2009). These conditions have been the driving force behind rehabilitation programs since the colonial eras with the main objective are to conserve soil and water.

Land rehabilitation is necessary to improve biological and habitat diversity at a landscape level, increase the productivity of land by planting trees to generate timber and non-timber products, enhance forest functions such as water storage, water balance, sequestration of carbon, climate mitigation, and restore soil fertility and physical properties for protection against erosion (Kobayashi et al. 2001). In other perspectives, land rehabilitation by tree planting can promote human well-being (i.e. economic benefits and quality of life) as described by Fisher et al. (1996). The economic benefits of rehabilitation can be in the form of additional incomes from selling timber and non-timber products, while the quality of life includes reduced heat effect, pollution reduction, fresh air and aesthetic view as the results of planting trees (Elmqvist et al. 2015; Roy et al. 2012).

Forest and land rehabilitation conducted either at a site level (i.e. small area consisting of single land management) or at a landscape scale (i.e., large area consisting of multiple land management) will affect different people in different ways. There were many cases of rehabilitation programs that failed because of the lack of involvement of local communities or ignorance of their interests when implementing the programs (Lamb and Gilmour 2003). Therefore, perception, acceptance, and participation by local communities in forest and land rehabilitation are important when designing forest rehabilitation programs to enhance feasibility and likelihood of success of the programs (Kobayashi 2004; Budiharta et al. 2016). Study by Soejono and Budiharta (2013) showed that there were some tree species preferred by the local community for rehabilitation of open area around water spring in Pasuruan East Java with the purposes of delivering ecological functions and providing socio-economic benefits. Study of trees preferences conducted by Salam et al. (2000) demonstrated that there are many factors influencing trees 
preference by farmers in agroforestry system in which the farmers preferred economic benefits rather than ecological concerns.

The selection of tree species for land rehabilitation needs several aspects to consider, including socioeconomic aspects, socio-cultural values, environmental services, general performance of tree species and biodiversity aspect whether the species are native or exotic/alien species (Reubens et al. 2011). While there are several studies on ecological aspects of forest and land rehabilitation, there is little information on social aspects particularly regarding community's preference on species selection and land uses management at watershed level. Several previous studies discussed the role of communities in selecting trees for land rehabilitation including trees preferences for water spring rehabilitation (Soejono and Budiharta 2013), rehabilitation of degraded land in Kenya (Glover 2012), selection of tree species in the form of agroforestry for slope stability in North Korea (He et al. 2015), and selection of trees for forest reforestation in the Philippines (Chechina and Hamann 2015). This research aimed to investigate the preference of villagers in selecting tree species for land rehabilitation programs in Sampean watershed, Bondowoso District, East Java, Indonesia and factors that influence those selections in regard to social, economic and ecological objectives of land management. We expect this study can enrich the limited studies on forest and land rehabilitation viewed from social perspective.

\section{MATERIALS AND METHODS}

\section{Study areas}

This study was conducted in Gubrih sub-watershed, Bondowoso, East Java on April-May 2016. Gubrih subwatershed is a part of Sampean watershed and encompasses three sub-districts, i.e. Wringin, Tegal Ampel and Pakem. Study location has temperature ranging from $20.4-25.9^{\circ} \mathrm{C}$ with average temperature of $25.7^{\circ} \mathrm{C}$. Average rainfall is $6475 \mathrm{~mm} /$ year with long rain time is 9 days per month. Minimum rainfall is $1622 \mathrm{~mm}$ in June while maximum rainfall is $13102 \mathrm{~mm}$ in January. Dry season occurs from June to October while the rainy season occurs from November to May. Soil type that dominates the study location is regosol (Bapeda Jawa Timur, 2013).

Forest cover in Bondowoso is 59.867,95 ha, consisting of watershed protection forest (hutan lindung) with an area of $30.863,70$ ha that covers $33,99 \%$ of Sampean watershed. Other land uses are timber plantation (kebun pohon), agroforestry (kebun campur), rice field (sawah), non-rice crop field (tegalan) and settlement area, covering of 7,59\%, $19,76 \%, 27,70 \%$, and 4,62\% respectively (Asmaranto et al. 2012). Previous study suggested that the ideal composition of land use in Sampean watershed consists of plantation and agroforestry areas with a portion $28.71 \%$ of total extent, rice fields $(3.12 \%)$, non-rice crop fields $(20.27 \%)$, and settlement (3.22\%) (Asmaranto et al. 2012). The gaps between the ideal and existing conditions especially on tree-based vegetation cover (i.e., plantation/agroforestry) requires study on how to increase such land cover through land rehabilitation.
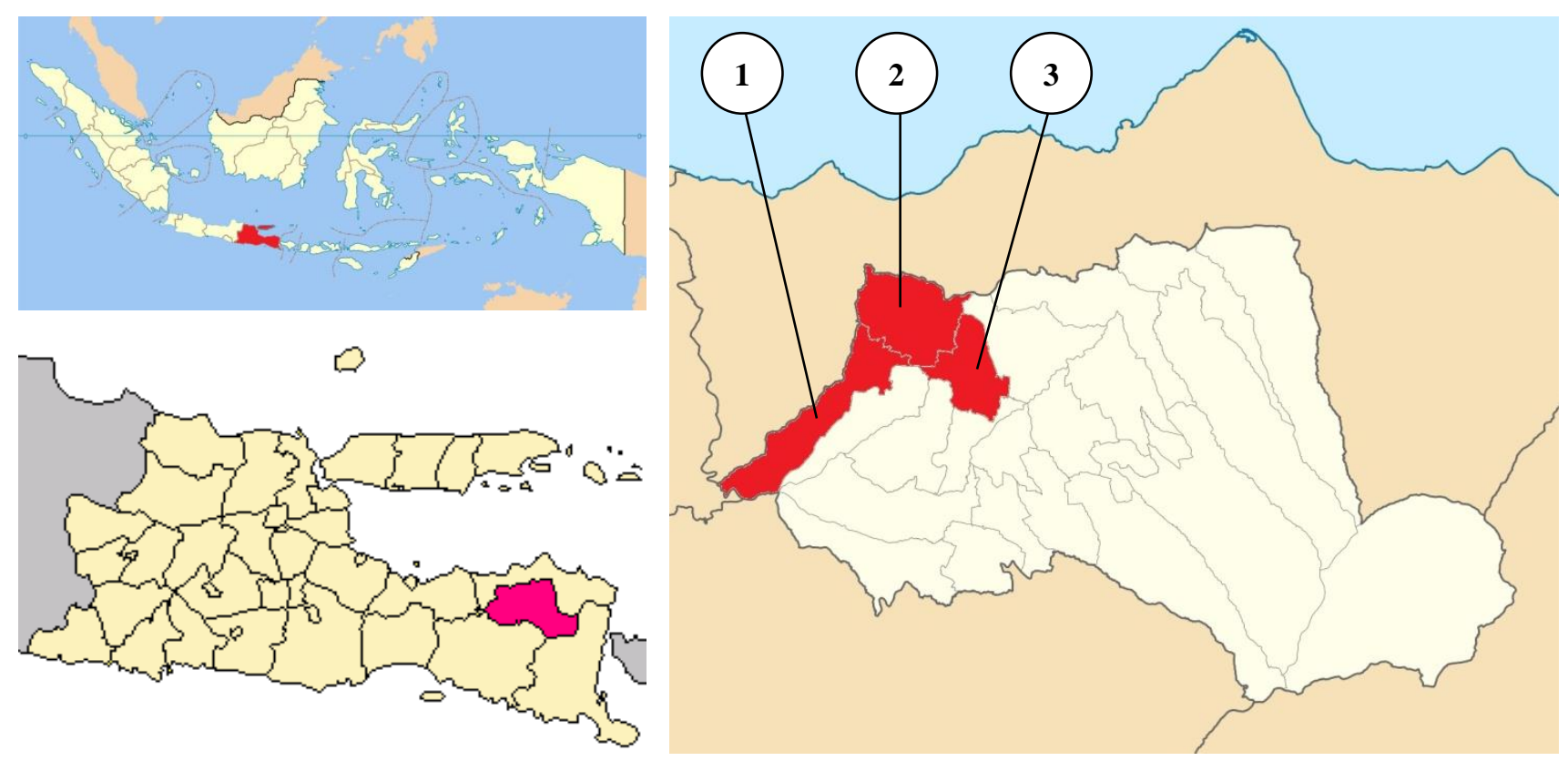

Figure 1. Study location in Gubrih sub-watershed, Sampean watershed, Bondowoso Distric, East Java Province, Indonesia which include Sub-districts of Pakem (1), Wringin (2), and Tegal Ampel (3) 
Table 1. Species of trees to select by respondents at the studied areas in Gubrih sub-watershed, Sampean watershed, Bondowoso District, East Java, Indonesia

\begin{tabular}{|c|c|c|c|}
\hline Species & Family & Local name & Potential uses \\
\hline Albizia procera (Roxb.) Benth. & Fabaceae & Wangkal & Ecology and economy \\
\hline Aleurites moluccanus (L.) Willd. & Euphorbiaceae & Kemiri & Ecology and economy \\
\hline Alstonia scholaris (L.) R. Br. & Apocynaceae & Pule & Ecology \\
\hline Anthocephalus cadamba (Roxb.) Miq. & Rubiaceae & Jabon & Economy \\
\hline Antidesma bunius (L.) Spreng. & Euphorbiaceae & Buni & Ecology \\
\hline Artocarpus altilis (Parkinson ex F.A.Zorn) Fosberg & Moraceae & Sukun & Ecology and economy \\
\hline Artocarpus heterophyllus Lam. & Moraceae & Nangka & Ecology and economy \\
\hline Bischofia javanica Blume & Phyllanthaceae & Gintungan & Ecology \\
\hline Buchanania arborescens (Blume) Blume & Anacardiaceae & Gerok ayam & Ecology \\
\hline Calophyllum inophyllum $\mathrm{L}$. & Clusiaceae & Nyamplung & Ecology \\
\hline Cananga odorata (Lam.) Hook.f. \& Thomson & Annonaceae & Kenanga & Ecology and economy \\
\hline Canarium vulgare Leenh. & Burseraceae & Kenari & Ecology \\
\hline Cassia javanica $\mathrm{L}$. & Fabaceae & Trengguli & Ecology \\
\hline Ceiba pentandra (L.) Gaertn. & Bombacaceae & Randu & Economy \\
\hline Coffea arabica $\mathrm{L}$. & Rubiaceae & Kopi & Economy \\
\hline Diospyros blancoi A.DC. & Ebenaceae & Bisbul & Ecology \\
\hline Dracontomelon dao (Blanco) Merr. \& Rolfe & Anacardiaceae & Rau & Ecology \\
\hline Durio zibethinus L. & Bombacaceae & Duren & Economy \\
\hline Dysoxylum gaudichaudianum (A.Juss.) Miq. & Meliaceae & Kedoyo & Ecology \\
\hline Erythrina orientalis Murray & Fabaceae & Dadap & Ecology \\
\hline Ficus variegata Blume & Moraceae & Gondang & Ecology \\
\hline Gmelina arborea Roxb. & Verbenaceae & Gmelina & Economy \\
\hline Leucaena leucocephala (Lam.) de Wit & Fabaceae & Lamtoro & Economy \\
\hline Litsea glutinosa (Lour.) C.B.Rob. & Lauraceae & Po ketek & Ecology \\
\hline Madhuca longifolia (J.Koenig ex L.) J.F.Macbr. & Sapotaceae & Kecik-kecik & Ecology \\
\hline Michelia alba DC. & Magnoliaceae & Cempaka & Ecology \\
\hline Pangium edule Reinw. & Achariaceae & Kluwek & Economy \\
\hline Paraserianthes falcataria (L.) I.C.Nielsen & Fabaceae & Sengon & Economy \\
\hline Parkia timoriana (DC.) Merr. & Fabaceae & Kedawung & Ecology \\
\hline Peltophorum pterocarpum (DC.) K.Heyne & Fabaceae & Saga & Ecology \\
\hline Persea americana Mill. & Lauraceae & Alpukat & Economy \\
\hline Pipturus sp. & Urticaceae & Senu & Ecology \\
\hline Pometia pinnata J.R.Forst. \& G.Forst. & Sapindaceae & Matoa & Ecology and economy \\
\hline Syzygium aqueum (Burm.f.) Alston & Myrtaceae & Jambu air & Economy \\
\hline Pterocarpus indicus Willd. & Fabaceae & Angsana & Ecology and economy \\
\hline Pterocymbium tinctorium Merr. & Palongan & Sterculiaceae & Ecology \\
\hline Sapindus rarak DC. & Sapindaceae & Klerek & Ecology \\
\hline Saraca indica $\mathrm{L}$. & Fabaceae & Asoka & Ecology \\
\hline Schleichera oleosa (Lour.) Merr. & Sapindaceae & Kesambi & Ecology \\
\hline Senna siamea (Lam.) H.S.Irwin \& Barneby & Fabaceae & Johar & Ecology \\
\hline Spondias dulcis Parkinson & Anacardiaceae & Kedondong & Economy \\
\hline Sterculia cordata Blume & Sterculiaceae & Kelumpang & Ecology \\
\hline Swietenia macrophylla King & Meliaceae & Mahoni & Economy \\
\hline Syzygium cumini (L.) Skeels & Myrtaceae & Juwet & Ecology \\
\hline Syzygium polyanthum (Wight) Walp. & Myrtaceae & Salam & Ecology and economy \\
\hline Tectona grandis L.f. & Lamiaceae & Jati & Economy \\
\hline Annona muricata $\mathrm{L}$. & Annonaceae & Sirsat & Economy \\
\hline Bambusa vulgaris Schrad. & Poaceae & Bambu & Ecology and economy \\
\hline Chrysophyllum cainito $\mathrm{L}$. & Sapotaceae & Buah Susu & Economy \\
\hline Citrus maxima (Burm.) Merr. & Rutaceae & Jeruk bali & Economy \\
\hline Cocos nucifera $\mathrm{L}$. & Arecaceae & Kelapa & Economy \\
\hline Dimocarpus longan Lour. & Sapindaceae & Kelengkeng & Economy \\
\hline Garcinia mangostana $\mathrm{L}$ & Clusiaceae & Manggis & Economy \\
\hline Gliricidia sepium (Jacq.) Kunth ex Walp. & Fabaceae & Gamal & Economy \\
\hline Gnetum gnemon L. & Gnetaceae & Melinjo & Economy \\
\hline Lansium domesticum Corrêa & Meliaceae & Duku & Economy \\
\hline Mangifera indica $\mathrm{L}$. & Anacardiaceae & Mangga & Economy \\
\hline Manilkara kauki (L.) Dubard & Sapotaceae & Sawo & Ecology \\
\hline Melia azedarach L. & Meliaceae & Mindi & Ecology \\
\hline Nephelium lappaceum L. & Sapindaceae & Rambutan & Economy \\
\hline Parkia speciosa Hassk. & Fabaceae & Petai & Economy \\
\hline Sesbania grandiflora (L.) Pers. & Fabaceae & Turi & Economy \\
\hline
\end{tabular}




\section{Data collection}

This study used questionnaires to collect data which were distributed randomly to respondents. Sampling method used in this survey was simple random sampling. This method allows each member of the population (villager) to have an equal chance of being selected to minimize bias (Groves et al. 2009). Survey was conducted in Gubrih Sub-watershed which encompasses three Subdistricts with total of 15 villages, i.e. Wringin Sub-districts (village: Gubrih, Jambe Wungu, Wringin, Ampelan, Sumber Malang, Jatisari, Banyuwuluh, and Banyuwuluh 2), Tegal Ampel Sub-districts (village: Tanggul Angin, Klabang Agung, Karanganyar, Mandiro, Sekar Putih, Klabang), and Pakem Sub-districts (village: Pakem). Total number of villagers being interviewed was 98 with gender composition of 63 males and 35 females. Each respondent was interviewed according to the list of questions contained in the questionnaire.

The questionnaire contains closed questions about tree species to select by the respondent for rehabilitation in Sampean Sub-watershed. The list of tree species was developed by identifying species with specific criteria in terms of ecological and economic perspectives. The ecological perspectives refer to tree species found at natural ecosystems nearby with similar biotic and abiotic factors, or so-called the reference site (Fiqa and Darmayanti 2017). In addition, tree species with high carbon sequestration were also considered to complement the ecological criteria (Danarto et al. 2013). Carbon sequestration is ability of plants to absorb $\mathrm{CO}_{2}$ from atmosphere and then store it as biomass (Hairiah et al. 2011). From economic perspective, tree species with economic value were considered. In the end, there were 62 species of trees to be selected by the respondents as shown in Table 1 .

In addition to species preference, analysis on factors affecting community preference in selecting particular tree species for land rehabilitation was also conducted. Basic information at respondent level was collected including age, gender, education level, access to transportation to their land (i.e. easy, moderate, difficult), topography of their land (i.e. flat, sloping, and steep), and primary occupation. Respondents were also asked about their perception of the importance and benefit of trees in their life, their preferred land management (i.e. timber plantation/kebun pohon, agroforestry/kebun campur, rice field/sawah, non-rice crop field/tegalan), and their acceptance for rehabilitation programs implemented on their lands.

\section{Statistical analysis}

Collected data were analyzed using Pearson Chi-square test to examine associations between two variables. In particular, we examined association between the variables of transport access versus preferred land management by the respondent, and between land topography versus preferred land management by the respondent. The equation for the Chi-square analysis is as follows:

$\mathrm{X}_{\mathrm{p}}^{2}=\Sigma \frac{(F i j-E i j)^{2}}{E i j}$, with df (degree of freedom $)=(\mathrm{R}-1)(\mathrm{C}-$ $1)$

$$
\begin{aligned}
& \text { Where: } \\
& \mathrm{X}^{2}{ }_{\mathrm{p}}=\text { chi-square analysis } \\
& \mathrm{F}_{\mathrm{ij}}=\text { observed value } \\
& \mathrm{E}_{\mathrm{ij}}=\text { expected value } \\
& \mathrm{R}=\text { number of lines } \\
& \mathrm{C}=\text { number of columns }
\end{aligned}
$$

The level of confidence to determine significance is $95 \%$, meaning that there is a significant association between variables if $p$ value $<0.05$ (Egbue and Long 2012).

\section{RESULTS AND DISCUSSIONS}

\section{Respondents' composition}

Education level varied among villagers with the highest proportions at the level of elementary school (Sekolah Dasar) with percentage of $48.97 \%$, followed by no receiving education with percentage of $12.24 \%$ (Figure2). Other educational levels, such as middle level, high level, and college level, had fewer percentage. Variable of age also varied among villagers. Most of respondents in this study had age of more than 40 years, while respondents with age of less than 30 years and between 30-40 years old had equal proportion (Figure 2).

\section{Preferred species of trees for rehabilitation programs by local community}

One step in rehabilitation of degraded areas is the selection of species of trees for rehabilitation programs which are preferred by local community to enhance community's acceptance and participation. The results of this study showed that among 62 tree species listed in the questionnaire, there were 45 species chosen by the local community for rehabilitation programs in Gubrih Subwatershed (Figure 3). Most of the selected tree species have economic potentials, including the potential for wood, fruits, cooking spices and stimulants. Highly preferred tree species are sengon (Paraserianthes falcataria), durian (Durio zibethinus), gmelina (Gmelina arborea), teak (Tectona grandis), avocado (Persea americana), coffee (Coffea robusta), jackfruit (Artocarpus heterophyllus), mahogany (Swietenia macrophylla), and breadfruit (Artocarpus altilis) and mangoes (Mangifera indica) in which each of them was selected by more than $20 \%$ of the respondents. Tree species such as klengkeng (Nephelium lappaceum), jeruk bali (Citrus maxima), jabon (Anthocephalus cadamba), lamtoro (Leucaena leucocephala) and kedondong (Spondias malayana) were moderately preferred as it was chosen by 6-20\% of the respondents. As many 21 species were less preferred by community with percentage of respondents ranging from 1$5 \%$ including manggis (Garcinia mangostana), buni (Antidesma bunius), matoa (Pometia pinnata), sawo (Manilkara kauki), buah susu (Chrysophyllum cainito), duku (Lansium domesticum), and sirsat (Annona muricata) (Figure 3).

Fruit trees are mostly cultivated in homegarden as fruit sources and microclimate controllers (temperature and light 
intensity controller). In addition, some of species are native trees with potentials of medicine, timber, and food, such as klerek (Sapindus rarak), pule (Alstonia scholaris), wangkal (Albizia procera), turi (Sesbania grandifolia), and belinjo (Gnetum gnemon). However, these species were chosen by only few respondents because they preferred tree species which has economic benefits for their life including commercial timber trees. For example, sengon ( $P$. falcataria) is a timber tree that can be harvested at the age of 5-6 years with wood volume reaching $300 \mathrm{~m}^{3}$ per hectare with potential income of 240 million rupiahs (Mulyana and Asmarahman 2012). In contrast, although species like klerek ( $S$. rarak) has the potentials for batik material, cloth cleaner, soap, biopesticides, acne treatment, shampoo, and shade plant and can be harvested at 5-6 years (Udarno 2012), but this species is rarely cultivated by community since it has limited commercial value.

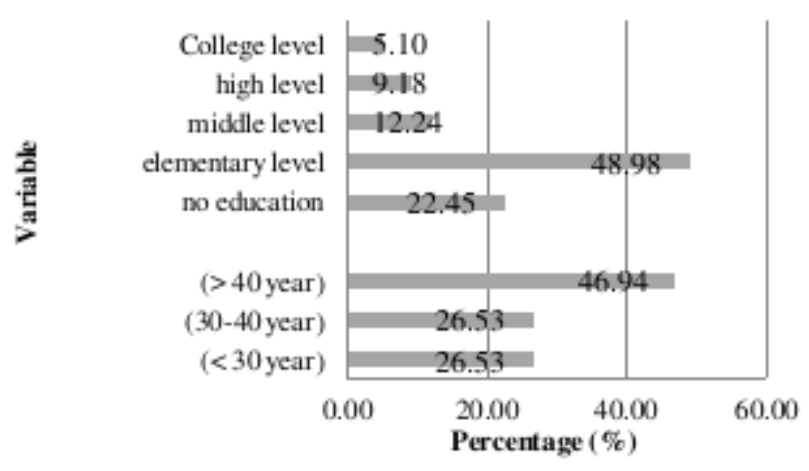

Figure 2. Basic data of respondents (age and education level) at the studied areas in Gubrih sub-watershed, Bondowoso District

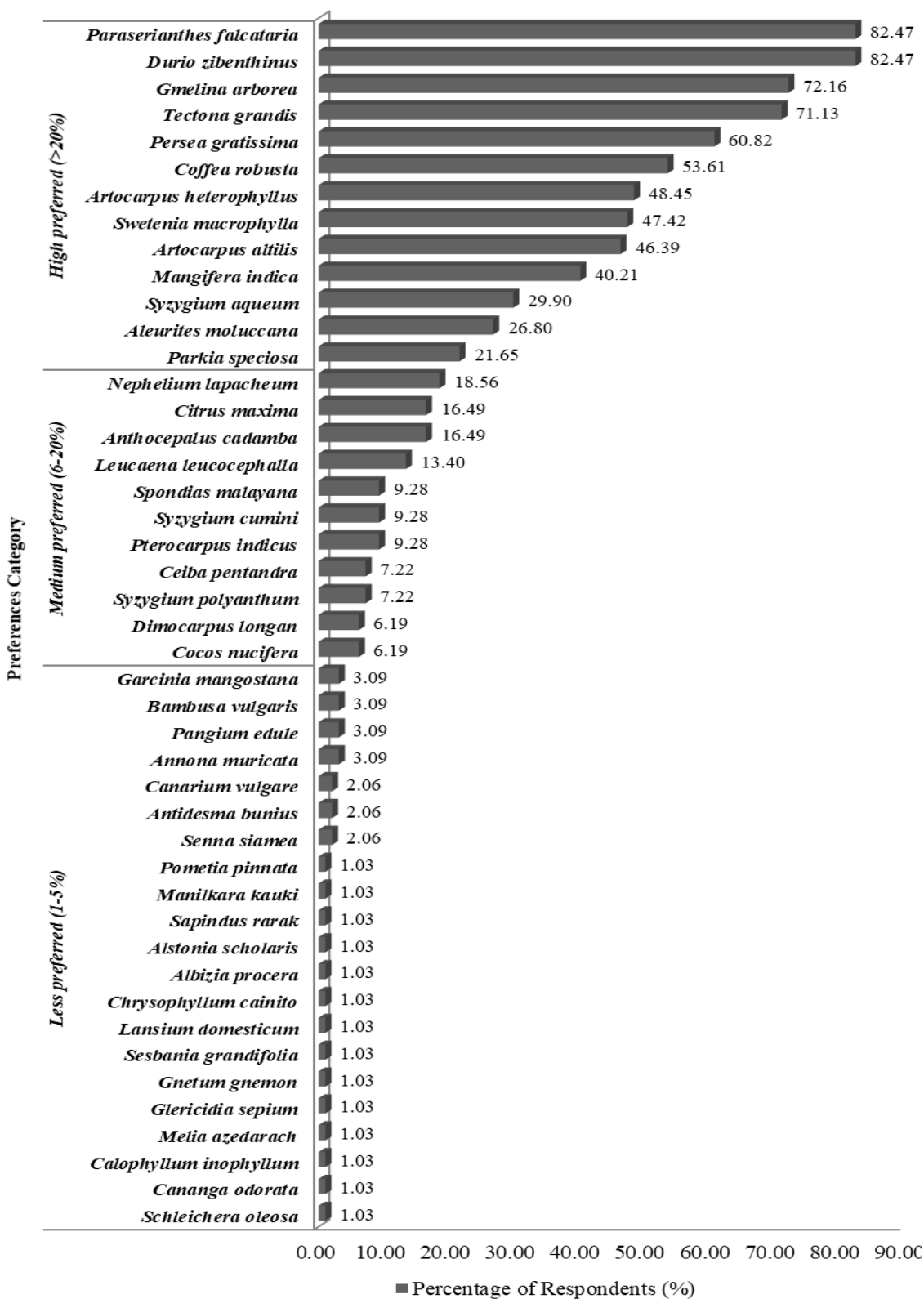

Figure 3. Percentage of respondents and tree species selected (45 species) for rehabilitation programs in Gubrih sub-watershed, Sampean watershed, Bondowoso District, East Java Province, Indonesia 
There were 17 species listed in the questionnaire that were not chosen by respondents with most of them are native trees found at the forest of the reference site. Reference site is a site with ecosystem that has similar biotic and abiotic conditions with the land to be restored or rehabilitated. In this study, we referred to trees found at protected forest of RPH Sentul, Probolinggo, East Java that had similar ecosystem conditions with Sampean watershed (Darmayanti and Fiqa 2017). These species included Bischofia javanica, Buchanania arborescens, Cassia javanica, Diospyros blancoi, Dracontomelon dao, Dysoxylum gaudichaudianum, Erythrina orientalis, Ficus variegata, Litsea glutinosa, Madhuca longifolia, Michelia alba, Parkia timoriana, Peltophorum pterocarpum, Pipturus sp., Pterocymbium tinctorium, Saraca indica, and Sterculia cordata. Although these species have biodiversity and ecological values, these species were not chosen by the respondents as they were not familiar with these species. In the other perspective, they assumed that these species lack of economic potentials. Bisbul (Diospyros blancoi), cempaka (Michelia alba), gerok ayam (Buchanania arborescens), gintungan (Bischofia javanica), kedawung (Parkia timoriana), kedoya (Dysoxylum gaudichaudianum), kelumpang (Sterculia cordata), walnuts (Canarium vulgare), nyamplung (Calophyllum inophyllum), krau (D. dao), saga (Peltophorum pterocarpum) are among 25 tree species that have high potentials in carbon sequestration in dry lowlands ecosystem (Danarto and Yulistyarini 2019). They are also commonly found in water springs of lowland ecosystems, so that the existence of these trees is very important for water conservation (Soejono et al. 2011).

Species of trees with potentials for timber and fruits were chosen by many respondents because these species have economic values. Sengon is one of timber tree categorized as fast-growing species so that it is widely cultivated by local community in Gubrih sub-watershed (Irawanti et al. 2017). Sengon is native to Indonesia, Papua New Guinea, Solomon Island, and Australia. This species can grow in a variety of habitat from dry to moist soil, even in acidic soil with good drainage. In Java, this species can be found on various types of soil with altitudes 0-1200 m above sea level (Soerianegara and Lemmens 1993). Besides sengon, other species which has timber potential in Bondowoso are teak (T. grandis), sonokeling (Dalbergia latifolia), and gmelina ( $G$. arborea). Both jati and sonokeling are species that contribute to high timber production in Bondowoso if compared to other timber trees such as sengon, mahogany, and pine. Data from Bondowoso Statistical Office in 2017 showed that production of timber in 2016 in the form of teak commodities reached $917.9 \mathrm{~m}^{3}$ with sonokeling wood production reaching 3,049 $\mathrm{m}^{3}$ (BPS Bondowoso 2017). Teak has been chosen by many people as a long-term investment and has high economic benefits. This tree species is native to India, Indonesia, Laos, Myanmar, Thailand. Teak trees are able to grow in dry to moist habitats with rainfall of $600-4000 \mathrm{~mm} /$ year at altitudes of 0-1200 $\mathrm{m}$ above sea level with an average annual temperature of $14-36^{\circ} \mathrm{C}$. The most suitable soil type is deep, well-drained soil, fertile alluvial-colluvial soil with a $\mathrm{pH}$ of 6.5-8 with high levels of calcium and phosphorus (Orwa et al. 2009). Most commercial timber trees planted in Bondowoso are cosmopolitan tree species that have wide adaptation to various climatic conditions and soil types.

Our findings suggest that there is a gap between ecological needs and socio-economic interests in the selection of species for land rehabilitation, especially in watershed landscapes. This is indicated by a mismatch between the list of species with ecological-biodiversity values and species with socio-economic preferences. Previous study in Rejoso watershed, Pasuruan District, East Java, local communities had several criteria in selecting tree species for rehabilitation under PES (Payment for Ecosystem Service) scheme (Leimona et al. 2018). The criteria included the tree species must be suitable with local habitat, it has good prices and accessible market to deliver high revenues, it must-have benefit for domestic consumption and the species possesses environmental and conservation values. Also, local communities preferred trees species that are consistent with their current farming system. Fruit and timber trees were preferred by smallholders downstream while agroforestry was mostly cultivated upstream (Leimona et al. 2018).

In various rehabilitation programs of degraded areas in Indonesia, tree species such as sengon, teak, gmelina, and jabon are widely planted by communities because these species have economic values. However, the lifetime of these species is not long because they would be harvested for their timber yield so that the rehabilitation goals for environmental improvement are not achieved (Soejono and Budiharta 2013). One of alternative for rehabilitation of degraded areas is using non-timber producing species which has long-term economic and environmental improvement potentials. From the selection of the villager population at the study sites, we propose several species of non-timber produced species that can be used for land rehabilitation in the studied area, including durian $(D$. zibethinus), avocado (P. americana), coffee (C. robusta), jackfruit (A. heterophyllus), mango (Mangifera indica), water guava (Syzygium aqueum), candlenut (Aleurites moluccana), petai (Parkia speciosa), rambutan ( $N$. lappaceum), jeruk bali (C. maxima), and lamtoro ( $L$. leucocephala). When cultivated, these species can be combined to form multi-strata agroforestry which not only can deliver non-timber products but also contributes to conserve water and soil (Budiharta et al. 2016).

Planting tree species for rehabilitation needs to consider habitat suitability, soil type, texture, soil structure and depth, climate, and water use efficiency (Soejono et al. 2011). Based on interviews with local community at the research location supported by literature studies from Orwa et al. (2009), Krisnawati et al. (2011), Harja et al. (2009), Soerianegara and Lemmens (1993), suitable habitat of trees species selected by the local community can be divided into three ranges of altitudes, namely low (0-400 m asl), medium (500-900 m asl) and high altitudes (mountainous with altitude $>900 \mathrm{~m}$ asl). Most of the tree species chosen by the local community at the studied areas can be planted from lowland to highland areas, including sengon ( $P$. 
falcataria), gmelina (G. arborea), teak (T. grandis), avocado ( $P$. americana), jack fruit (A. heterophyllus), mahogany ( $S$. macrophylla), bread fruit (A. altilis), mangoes (Mangifera indica), guava ( $S$. aqueum), candle nut (Aleurites moluccana), and lamtoro (L. leucocephala). On the other hand, the preferred species that can be cultivated from lowland up to medium altitudes are durian ( $D$. zibethinus), guava ( $S$. aqueum) and rambutan ( $N$. lappaceum). While jeruk bali (C. maxima) can only be cultivated in lowland ecosystems. Suitable habitat for the preferred trees by the local community in the studied area is shown in Table 2.

The research location has an average rainfall of 1000$2500 \mathrm{~mm} /$ year with soil is categorized as clay and loam soil. Durian (D. zibethinus) is cultivated by villager from middle to highland combined with other fruit trees such as avocado ( $P$. americana), coffee (C. robusta), banana (Mussa accuminata), rambutan (N. lappaceum), and jeruk bali (C. maxima). Bondowoso is one of district that supplies durian in Indonesia with total production of 11.196 tons (Fitri and Islahudin 2018). Other species such as coffee $(C$. robusta) are cultivated from middle to highland and can be combined with other fruit trees within agroforestry system. Coffee is suitable to be cultivated within the range of altitude from 1300 to $3000 \mathrm{~m}$ asl with temperature of $15-25^{\circ} \mathrm{C}$ and average rainfall 500-2000 $\mathrm{mm} /$ year. Soil classes suitable for coffee cultivation are loamy soil with deep solum, slightly acid, and well drainage. The soils should be rich in nutrients especially potassium with generous supply of organic matter (Orwa et al. 2009). Agroecologically, both plants are suitably cultivated in Bondowoso. A previous study showed that avocado, durian, clove and perennial crops that were combined in agroforestry systems in Bondowoso were profitable with NPV (Net Present Value) of Rp. 21.483.580 per hectare (Hariyati 2013).

\section{Local community perception toward land rehabilitation}

The results of the survey indicated that local community in Gubrih sub-watershed, Sampean watershed has a different perception regarding land rehabilitation in their area (Figure 4). The figure shows that the respondents in the area understood the importance of trees in their lives and trees deliver benefits to them. However, there were some respondents saying that trees are not important for their lives and they also have poor knowledge about the benefits of trees.

The perception of local people about the importance of trees in their lives indicates that local people use trees for various needs, including as income sources, conserving spring water, and disaster mitigation with most of them stating that trees are important for the purpose to increase income. Bondowoso is one of the poor regions (daerah tertinggal) in Indonesia with problems including low human development index, poverty, and lack of basic facilities, such as health, education and road infrastructure (Bondowoso Spatial Plan Agency 2011; Puspasari and Koswara 2016). Community welfare in Bondowoso needs to be increased to reduce the poverty level. There is
$90.08 \%$ of total land area in Bondowoso used for agricultural land, including rice fields, non-rice crop fields (tegalan), plantations, forestry, swamps, and ponds. Most villagers in Bondowoso work in the sector of agriculture, forestry, and fisheries. Commodities cultivated in plantations in Bondowoso include coconut, areca nut, kapok, cashew nut, arabica coffee, robusta coffee, cloves, kasturi tobacco, sugar cane, and tobacco, whereas fruit species include mango, banana and durian (BPS Bondowoso 2018). Since most of the communities in the survey locations utilized trees and plants as a source of income, this can be combined with efforts to rehabilitate land by focusing on species with multiple benefits, not only to improve environment quality (i.e. ecological objective) but also to enhance community's welfare (socio-economic objective). The potential land management system to support rehabilitation efforts in the study region includes plantation of timber species and agroforestry system which can be implemented in land management currently under non-rice crop field (tegalan).

\section{Influencing variables of community's preference}

Land topography and access influenced the preference of land use systems by local community in Gubrih subwatershed. Based on the results of Chi-square Pearson statistical analysis, there was a correlation between topography and the selection of land management systems by local community ( $p$-value $<0.05$ ). Dryland agricultural systems, either in the form of padi gogo rice field or other crops field (tegalan) were mostly preferred by villagers from low to medium altitudes and on flat locations, but this was not the case in the area with steep topography in which most respondents preferred agroforestry (Figure 5).

There was also a correlation between variable of access and the selection of land management systems by community with Chi-square Pearson value of 10.33 ( $\mathrm{p}$ value<0.05). For all categories of access (i.e., easy, moderate and difficult), many villagers preferred plantation of timber species and agroforestry system because they assumed that both systems of land use were profitable (Figure 6). Yet, for all categories of access, land use system of dry land rice cultivation (padi gogo) was still chosen by the villagers although the percentage was smaller than plantation of timber species and agroforestry.

The finding of the relationship between land management and accessibility is in accordance with other studies. The more difficult is the access of a land management system, the higher is the likelihood a land being managed for tree-based land-use systems such as forest and agroforestry. Vice versa, the easier is the access to transportation, the more likely a land is managed under intensive agriculture, such as rice field and non-rice crop fields (tegalan). Several factors that influence land use functions in watersheds include the presence of infrastructure, agricultural expansion, timber extraction. Access to transportation triggers migration and forest clearing for plantations (Geist and Lambin 2002; Verbist et al. 2005; Busch and Gallon 2017). 
Table 2. Environmental suitability for 14 species preferred by local community in Gubrih sub-watershed, Sampean watershed, Bondowoso District, East Java Province, Indonesia

\begin{tabular}{|c|c|c|c|c|}
\hline Species & $\begin{array}{l}\text { Altitude } \\
\text { (m asl) }\end{array}$ & Soil type & Potentials & References \\
\hline Paraserianthes falcataria & $0-1200$ & $\begin{array}{l}\text { Deep, well-drained fertile soils, such as friable clay } \\
\text { loam. Prefers alkaline to acid soils. }\end{array}$ & Timber & Orwa et al. (2009) \\
\hline Gmelina arborea & $0-1200$ & $\begin{array}{l}\text { Preference for moist, fertile, freely drained soils; acid } \\
\text { soils, calcareous soils and laterite soils. }\end{array}$ & Timber & Orwa et al. (2009) \\
\hline Tectona grandis & $0-1200$ & $\begin{array}{l}\text { Their most suitable soil is deep, well-drained, fertile } \\
\text { alluvial-colluvial soil with a pH of } 6.5-8 \text { and a } \\
\text { relatively high calcium and phosphorous content. The } \\
\text { quality of growth, however, depends on the depth, } \\
\text { drainage, moisture status and fertility of the soil. Teak } \\
\text { does not tolerate waterlogging or infertile lateritic } \\
\text { soils. }\end{array}$ & Timber & Orwa et al. (2009) \\
\hline Persea americana & $0-2500$ & $\begin{array}{l}\text { Requires well-drained aerated soil. A pH of } 5-5.8 \text { is } \\
\text { optimal for growth and fruit yield. }\end{array}$ & Fruit & Orwa et al. (2009) \\
\hline Artocarpus heterophyllus & $0-1600$ & $\begin{array}{l}\text { Deep, alluvial, sandy-loam or clay loam soils of } \\
\text { medium fertility, good drainage and a pH of 5-7.5. } \\
\text { This species tolerance to saline soils }\end{array}$ & $\begin{array}{l}\text { Timber, } \\
\text { fruit and } \\
\text { vegetable }\end{array}$ & Orwa et al. (2009) \\
\hline Swietenia macrophylla & $0-1500$ & Well-drained soils. & Timber & Orwa et al. (2009) \\
\hline Artocarpus altilis & $\begin{array}{l}0-1550 \\
\text { (optimum } \\
\text { growth at } \\
600-650 \text { ) }\end{array}$ & $\begin{array}{l}\text { Alluvial and coastal soils, deep, fertile, well-drained } \\
\text { sandy loam or clay loam soils. }\end{array}$ & $\begin{array}{l}\text { Timber, } \\
\text { fruit and } \\
\text { vegetable }\end{array}$ & Orwa et al. (2009) \\
\hline Mangifera indica & $0-1200$ & $\begin{array}{l}\text { Mango trees thrive in well-drained soils with } \mathrm{pH} \\
\text { ranging from } 5.5 \text { to } 7.5 \text { and are fairly tolerant of } \\
\text { alkalinity. For good growth, they need deep soil to } \\
\text { accommodate the extensive root system. }\end{array}$ & Fruit & Orwa et al. (2009) \\
\hline Syzygium aqueum & $0-1200$ & $\begin{array}{l}\text { The trees prefer heavy soils and easy access to water } \\
\text { instead of having to search for water in light deep soils. }\end{array}$ & Fruit & $\begin{array}{l}\text { Panggabean } \\
(2016)\end{array}$ \\
\hline Aleurites moluccana & $0-1200$ & Sandy, clay, loam soil with pH 5-8. & Spices & $\begin{array}{l}\text { Krisnawati et al. } \\
(2011)\end{array}$ \\
\hline Leucaena leucocephala & $0-1500$ & $\begin{array}{l}\text { Optimal growth on calcareous soils but can be found } \\
\text { on saline soils and on alkaline soils up to } \mathrm{pH} 8 \text {; it is } \\
\text { not tolerant of acid soils or waterlogged conditions. } L \text {. } \\
\text { leucocephala is known to be intolerant of soils with } \\
\text { low pH, low phosphorus, low calcium, high salinity, } \\
\text { high aluminum saturation and water-logging and has } \\
\text { often failed under such conditions. }\end{array}$ & $\begin{array}{l}\text { Fruit, } \\
\text { firewood }\end{array}$ & Orwa et al. (2009) \\
\hline Durio zibethinus & $300-800$ & Deep soil, well-drained, light sandy or loamy soil. & Fruit, timber & Orwa et al. (2009) \\
\hline Nephelium lappaceum & $0-600$ & Clay loam soil, pH 5-6.5. & Fruit & Orwa et al. (2009) \\
\hline Citrus maxima & $0-400$ & Tolerate from coarse sand to heavy clay & Fruit & Orwa et al. (2009) \\
\hline
\end{tabular}

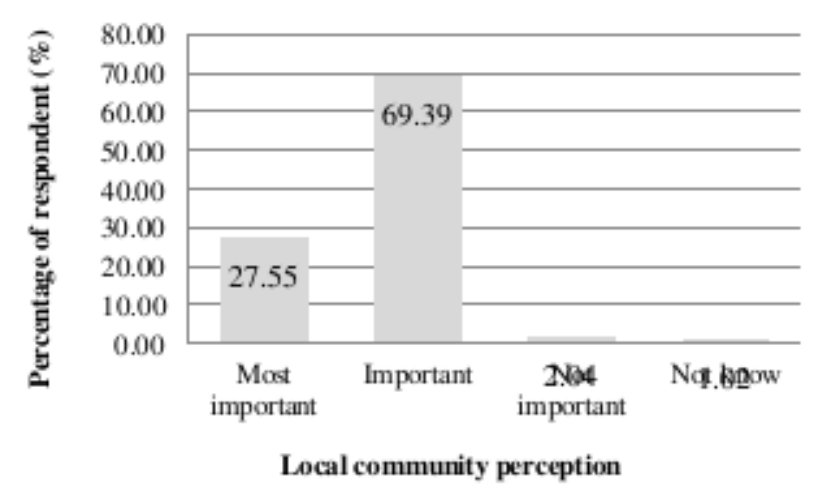

Figure 4. Perception of local community on the benefit of trees in their life

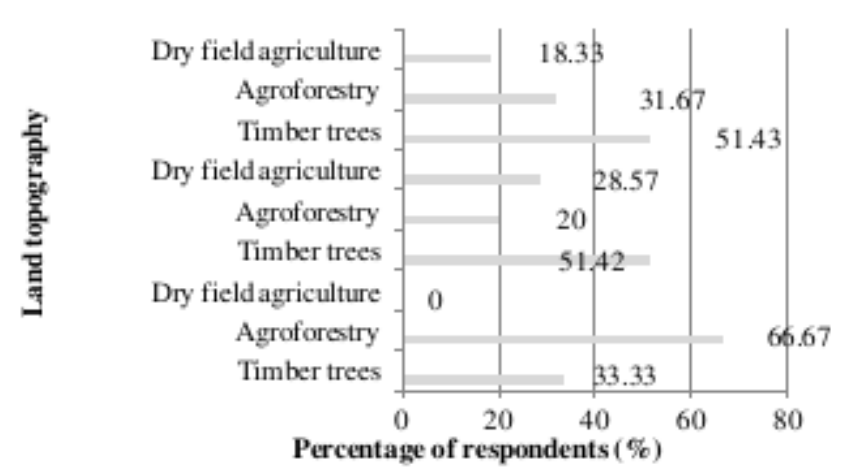

Figure 5. Land use system preferred by local community based on categories of land topography 


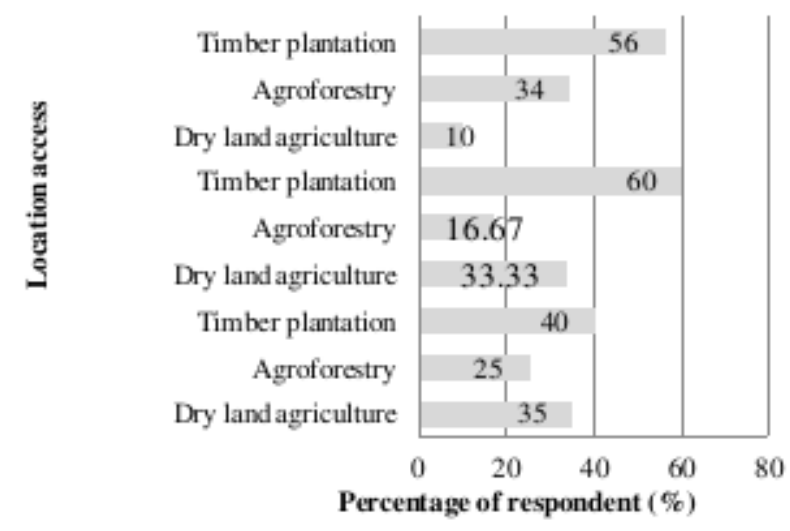

Figure 6. Land use system preferred by local community based on categories of location access

Based on interviews with respondents, timber plantation and agroforestry were considered to have economic advantages compared to other land uses. Agroforestry system is ecologically and economically beneficial. Agroforestry system at the studied area was a mixed system of combination of several species of fruit trees and seasonal crops. The villagers at the survey location stated that the agroforestry system increased income of their life. Difficult access to transportation to traditional markets causes local communities preferred for agroforestry and timber plantation for economic investment purposes.

Agroforestry increases community income and environmental services compared to conventional farming systems (Mercer et al. 2014). A previous study showed that coffee farming in Bondowoso is beneficial with $\mathrm{R} / \mathrm{C}$ is 1.85. Another study showed that commercial agroforestry in India is profitable with Benefit to Cost $(\mathrm{B} / \mathrm{C})$ ratio is 6.59 for annual crop-based tree agroforestry (Sangeetha et al. 2015). A case study in East Kalimantan, vanilla and agarwood agroforestry are also profitable with profit rate of $15 \%$ and IRR of $21.5 \%$ (Kunio and Lahjie 2015) while agroforestry in Sukoharjo Pringsewu Village contributes to the income of farmers with benefit percentage of $88.31 \%$ (Olivi et al. 2015).

In conclusion, of the 62 tree species listed in the questionnaire, there were 45 species of trees selected by respondents in Gubrih sub-watershed with 13 species were highly preferred. The respondents understood the importance of trees as a source of income as well as a measure to conserve spring water and mitigate disasters, such as landslides and floods. This selection of species was strengthened with land-use systems they preferred, which were tree-based land-use systems such as plantation of timber species and agroforestry. This preference is influenced by access to transportation and land topography. The findings of this study suggest that there is opportunity in rehabilitating degraded lands in Sampean watershed using tree species preferred by local communities under the land use system of timber plantation or agroforestry. A list of species resulting from this study can provide insights when establishing nurseries and producing seedlings for rehabilitation programs.

\section{ACKNOWLEDGEMENTS}

The authors would like to thank Purwodadi Botanic Garden-LIPI, Pasuruan, Indonesia for funding this research through DIPA of Sampean watershed rehabilitation 20152016. We also express gratitude to team members i.e., Abdul Goni, and Jafar who was involved in interview with respondent. We would like to thanks to Gatot Tri Handoyo from UPT PHW VII Bondowoso for research permit in Bondowoso and Edi Susanto for guidance during study.

\section{REFERENCES}

Anonim. 2019. Peta Kecamatan Kabupaten Bondowoso Jawa Timur. http:https:/www.sejarah-negara.com/2017/10/peta-kabupatenbondowoso-jawa-timur.html. [Indonesian]

Asmaranto R, Suhartanto E, Permana BA. 2012. Aplikasi sistem informasi geografis sig untuk identifikasi lahan kritis dan arahan fungsi lahan daerah aliran sungai sampean. Irrig Eng J 12: 84-105.

Bapeda Jawa Timur. 2013. Bondowoso Districts. http:// bappeda.jatimprov.go.id/bappeda/wp...kab.../kab-bondowoso2013.pdf. [Indonesian]

Bondowoso Spatial Plan Agency. 2011. Spatial Plan of Bondowoso District East Java Province 2011-2031. Bondowoso District, Bondowoso. [Indonesian]

Budiharta S, Meijaard E, Wells JA, Abram NK, Wilson KA. 2016. Enhancing feasibility: Incorporating a socio-ecological systems framework into restoration planning. Environ Sci Policy 64: 83-92. DOI: 10.1016/j.envsci.2016.06.014

Busch J, Ferretti-Gallon K. 2017. What drives deforestation and what stops it? a meta-analysis. Rev Environ Econ Policy 111: 3-23. DOI: 10.1093/reep/rew013

Central Bureau of Statistic. 2017. Bondowoso District in The Numbers, Year 2017. Central Bureau of Statistic of Bondowoso District, Bondowoso. [Indonesian]

Central Bureau of Statistic. 2018. Bondowoso District in The Numbers, Year 2018. Central Bureau of Statistic of Bondowoso District, Bondowoso. [Indonesian]

Chechina M, Hamann A. 2015. Choosing species for reforestation in diverse forest communities: social preference versus ecological suitability. Ecosphere 6: 1-13. DOI: 10.1890/ES15-00131.1

Danarto SA, Yulistyarini T, Sofiah S, Darmayanti AS, Fiqa AP, Laksono RA, Suhadinoto, Mukaromah L, Soejono. 2013. Selection of lowland trees that high carbon sequestration potency on lowland ecosystem. Research report. Purwodadi Botanic Garden, Pasuruan. [Indonesian]

Danarto SA, Yulistyarini T. 2019. Selection of lowland plants with high potention of carbon stock for rehabilitation of degraded lands. In: Setyawan AD, Sugiyarto, Pitoyo A, Widiastuti A, Windarsih G, Supatmi, Munir B, Witono JR (eds) Proceeding of National Seminar Indonesian Biodiversity Community. Bogor, 28 September 2018. [Indonesian]

Darmayanti AS, Fiqa AP. 2017. The canopy structure and its impact on hydrological performance of five local trees species grown in the Purwodadi Botanic Garden. J Trop Life Sci 7(1): 40-47.

Egbue O, Long S. 2012. Barriers to widespread adoption of electric vehicles: An analysis of consumer attitudes and perceptions. Energy Policy 48: 717-729. DOI: 10.1016/j.enpol.2012.06.009

Elmqvist T, Setälä H, Handel S N, Van Der Ploeg S, Aronson J, Blignaut JN, Baggethun-Egómez, Nowak DJ, Kronenberg J, \& De Groot R. 2015. Benefits of restoring ecosystem services in urban areas. Current Opin Environ Sustain 14: 101-108. DOI: 10.1016/j.cosust.2015.05.001

Faisol A, Indarto I. 2010. Soil erosion prediction using GIS and RUSLE: study at Sampean Watershed. J Trop Soils 15: 147-152. DOI: 10.5400/jts.2010.v15i2.147-152

Fiqa AP, Darmayanti, AS. 2017. Floristic and soil characteristics at the RPH Sentul-Probolinggo protected low land forest, east java. Journal of Tropical Biodiversity and Biotechnology 31: 18-25. DOI: 10.22146/jtbb.30208 
Fisher RJ, Dechaineux R, Keonuchan KK. 1996. Socio-Economic Baseline Survey and Evaluation Methodology. Consultants Report 2/96, NTFP Project, Department Forestry, Vientiane, Lao LDR.

Fitri MZ, Islahuddin M. 2018. Pengaruh lama penyatuan dan sambung sistem kaki ganda terhadap pertumbuhan bibit durian (Durio zibenthinus, L.) di Kabupaten Jember. Agritrop: J Agric Sci 16: 283291. DOI: 10.32528/agritrop.v16i2.1812 [Indonesian]

Geist HJ, Lambin EF. 2002. Proximate causes and underlying driving forces of tropical deforestation tropical forests are disappearing as the result of many pressures, both local and regional, acting in various combinations in different geographical locations. BioScience 522: $143-150$. DOI: $10.1641 / 0006$ 3568\%282002\%29052\%5B0143:PCAUDF\%5D2.0.CO;2

Glover E. 2012. Local knowledge and tree species preference for land rehabilitation in Kenya. Int J Soc For 5(1): 57-83.

Groves RM, Fowler Jr FJ, Couper MP, Lepkowski JM, Singer E, Tourangeau R. 2009. Survey Methodology. John Wiley \& Sons, New Jersey, Canada.

Hairiah K, Ekadinata A, Sari RR, Rahayu S. 2011. Pengukuran Cadangan Karbon: dari Tingkat Lahan ke Bentang Lahan. Petunjuk praktis. Edisi kedua. World Agroforestry Centre, ICRAF SEA Regional Office, University of Brawijaya (UB), Malang, Indonesia. [Indonesian]

Hariyati Y. 2013. Analisis usaha tani kakao rakyat di berbagai pola tanam tumpang sari. J Agribisnis Indonesia 1(2): 155-166. [Indonesian]

Harja D, Rahayu S, Pambudi S. 2009. Tree functional attributes and ecological database. http:// http://db.worldagroforestry.org//species.

He J, Ho MH, Xu J. 2015. Participatory selection of tree species for agroforestry on sloping land in North Korea. Mount Res Develop 35(4): 318-328. DOI: 10.1659/MRD-JOURNAL-D-15-00046.1

Irawanti S, Race D, Stewart H, Parlinah N, Suka AP. 2017. Understanding the timber value chain in community-based forestry in Indonesia: Analysis of sengon in Central Java. J Sustain For 368: 847-862. DOI: 10.1080/10549811.2017.1381029

Kobayashi S, Turnbull JW, Cossalter C. 2001. Rehabilitation of degraded forest ecosystems project. In: Kobayashi S, Turnbull JW, Toma T, Mori T, Madjid NMWA (eds) Proceeding of Rehabilitation of Degraded Tropical Forest Ecosystems. Cifor, Bogor, 2-4 November 1999. [Indonesian]

Kobayashi S. 2004. Landscape rehabilitation of degraded tropical fores ecosystems: case study of the CIFOR/Japan project in Indonesia and Peru. For Ecol Manag 2011: 13-22. DOI: 10.1016/j.foreco.2004.06.009

Krisnawati H, Kallio M, Kanninen M. 2011. Aleurites moluccana (L.) Willd.: Ecology, Silviculture and Productivity. CIFOR, Bogor.

Kunio K, Lahjie AM. 2015. Agroforestry management with vanilla and agarwood in East Kalimantan. J Econ Sustain Develop 64: 12-17.

Lamb D, Gilmour D. 2003. Rehabilitation and Restoration of Degraded Forests. IUCN-The World Conservation Union, Switzerland.

Leimona B, Khasanah N, Lusiana B, Amaruzaman S, Tanika L, Hairiah K, Suprayogo D, Pambudi S, Negoro FS. 2018. A business case: coinvesting for ecosystem service provisions and local livelihoods in Rejoso watershed. World Agroforestry Centre (ICRAF) Southeast Asia Regional Program, Bogor, Indonesia. [Indonesian]
Mercer DE, Cubbage FW, Frey GE. 2014. Economics of agroforestry In: Kant S, Alavalapati JRR (eds) Handbook of Forest Economics. Earthscan from Routledge, New York.

Morgan RPC. 2009. Soil Erosion and Conservation. John Wiley Sons, USA.

Mulyana D Asmarahman, C. 2012. Untung Besar dari Bertanam Sengon. Agro Media, Jakarta Selatan. [Indonesian]

Nawir AA, Murniati, Rumboko L. 2007. Forest Rehabilitation in Indonesia: Where to After More than Three Decades?. Center for International Forestry Research CIFOR, Bogor.

Olivi R, Qurniati R. 2015. Kontribusi agroforestri terhadap pendapatan petani di Desa Sukoharjo 1 Kecamatan Sukoharjo Kabupaten Pringsewu. J Sylva Lestari 32: 1-12. [Indonesian]

Orwa C, A Mutua, Kindt R, Jamnadass R, S Anthony. 2009. Agroforestry database: a tree reference and selection guide version 4.0 http://www.worldagroforestry.org/sites/treedbs/treedatabases.asp

Panggabean G. 2016. Prosea: Syzygium aqueum (Burm.f.) Alston. https://uses.plantnet-project.org/en/Syzygium_aqueum_(PROSEA)

Puspasari A, Koswara AY. 2016. Arahan pengembangan desa tertinggal Kabupaten Bondowoso berdasarkan aspek sosial, ekonomi, dan infrastruktur. Eng J ITS 52: 108-111. [Indonesian]

Reubens B, Moeremans C, Poesen J, Nyssen J, Tewoldeberhan S, Franzel S, Deckers S, Orwa C, Muys B. 2011. Tree species selection for land rehabilitation in Ethiopia: from fragmented knowledge to an integrated multi-criteria decision approach. Agrofor Systems 823: 303-330. DOI: 10.1007/s10457-011-9381-8

Roy S, Byrne J, Pickering C. 2012. A systematic quantitative review of urban tree benefits, costs, and assessment methods across cities in different climatic zones. Urban For Urban Greening 114: 351-363. DOI: $10.1016 /$ j.ufug.2012.06.006

Salam MA, Noguchi T, Koike M. 2000. Understanding why farmers plant trees in the homestead agroforestry in Bangladesh. Agrofor Syst 501: 77-93. DOI: 10.1023/A:1006403101782

Sangeetha R, Shanmugam TR. 2015. External benefit and external cost in the economics agroforestry systems in northwestern parts of Tamil Nadu. Int J Commerce Business Manag 81: 28-35.

Soejono Budiharta S, Arisoesilaningsih E. 2013. Proposing local trees diversity for rehabilitation of degraded lowland areas surrounding springs. Biodiversitas 14: 37-42. DOI: 10.13057/biodiv/d140106

Soejono. 2011. The trees species diversity around spring at two areas in Purwodadi. In: Sancayaningsih P, Sembiring L, Mulyati, Semiarti E, Soetarto ES, Austin C, Bessho Y (eds) Proceeding International Conference on Biological Science. Faculty of Biology Gadjah Mada University, Yogyakarta, 23-24 September 2011 [Indonesian]

Soerianegara I, Lemmens RHMJ. 1993. Plant Resources of Southeast Asia. No. 5(1) Timber Trees: Major Commercial Timbers. LIPI Press, Indonesia. [Indonesian]

Udarno L. 2009. Lerak (Sapindus rarak) tanaman industri pengganti sabun. Warta Penelitian dan Pengembangan Tanaman Industri 15 (2): 7-8. [Indonesian]

Verbist B, Putra AED, Budidarsono S. 2005. Factors driving land-use change: Effects on watershed functions in a coffee agroforestry system in Lampung, Sumatra. Agri Syst 853: 254-270. DOI: 10.1016/j.agsy.2005.06.010 